\title{
Early EFL Instruction and L1 Literacy
}

\section{Instrucción temprana en inglés como lengua extranjera y desarrollo de literacidad en primera lengua}

\author{
Kristen M LindahI ${ }^{1}$ \\ Peter Sayer ${ }^{2}$
}

Citation/ Para citar este Artículo: Lindahl, K., \& Sayer, P. (2018). Early EFL Instruction and L1 Literacy. Colomb. Appl. Linguistic. J., 20(2), pp. 184-194. Received: 19-Dic.-2017 / Accepted: 20-Jul.-2018

DOI: https://doi.org/10.14483/22487085.12900

\begin{abstract}
This study investigates the relationship between early English as a foreign language (EFL) learning and L1 literacy development in Mexican public schools. Researchers sought confirmatory findings about whether and in which ways early EFL exposure may affect students' L1 literacy skills via a study evaluating the L1 Spanish literacy of 61 first graders using an adapted literacy assessment. Experimental group participants received EFL instruction during grades K-1, and those in the control group did not. A one-way independent samples comparison of means on the literacy assessment revealed that participants from the experimental group who had received EFL instruction scored significantly higher on all sections of the assessment than those participants in the control group. Results may inform programmatic decision-making about simultaneous or sequential approaches on the impact of early EFL on biliteracy development, with broader implications that examine who has access to early EFL instruction, and whether it will ultimately lead to higher L2 proficiency.
\end{abstract}

Keywords: bilingualism, English as a foreign language, literacy, public schools

\section{Resumen}

Este estudio investiga la relación entre enseñanza del inglés como lengua extranjera y el desarrollo de habilidades de literacidad en las escuelas públicas mexicanas. Los investigadores buscaron resultados confirmatorios sobre si y en qué manera la exposición al inglés como lengua extranjera durante la escuela primaria afectaría el desarrollo de su literacidad. En una investigación cuantitativa, ellos evaluaron la literacidad de 61 estudiantes del primer grado con un examen que mide su literacidad. Participantes en el grupo experimental fueron expuestos a instrucción en Inglés, y los del grupo control, no. Una comparación de los puntajes promedios entre los dos grupos reveló una diferencia significativa en que los participantes del grupo expuesto a la instrucción en Inglés salieron mejor que los participantes que no recibieron instrucción en Inglés. Los resultados pueden informar decisiones sobre programas de Inglés en escuelas primarias y si deben ser simultáneo o secuencial. También, los resultados tienen implicaciones que pueden informar de quien y cuales tipos de escuelas tienen acceso a programas de inglés en escuelas primarias, y si la participación en programas de Inglés ayudaría con el desarrollo con la literacidad en su primer idioma.

Palabras clave: literacidad, bilingüismo, escuelas públicas, Inglés como idioma extranjero

1 University of Texas at San Antonio. United States. kristen.lindahl@utsa.edu

2 The Ohio State University. United States. sayer.32@osu.edu 


\section{Introduction}

As English has become an increasingly prominent global language, language education policy in many countries has shifted to respond. Recently, there has been a marked trend towards the inclusion of English in public school curriculum starting in the primary grades. The movement towards "primary English language teaching" $(\mathrm{PELT})^{3}$ reflects the perceived need for students to begin studying English at a younger age in order to develop a higher level of communicative competence (Enever, 2012). This "more and earlier" approach has been adopted widely by Ministries of Education in so-called developing countries, especially in Latin America, and has been premised on an argument that more widespread English proficiency is needed for the country to become globally competitive (Hamid, 2010; Author, 2015a).

Despite a surge in the investment of resources into new PELT program implementation internationally (Nikolov E Djigunovic, 2006), relatively little research exists on what sorts of pedagogical approaches, practices, materials, and assessments may yield the most favorable language learning outcomes, especially in public school settings. Knell and co-authors (2007), writing about the PELT program in China, observed: "Instruction in English as a foreign language at an early age is becoming more common world-wide even though the effects of this early instruction are not yet known" (p. 395, emphasis added). Still fewer studies have explored the intersection between PELT implementation, literacy development, and socioeconomic status (SES). Because research into factors that mediate the effectiveness of PELT programs in English as a Foreign Language (EFL) contexts lags considerably behind policy and program implementation, the purpose of the present study was to help close this gap by looking specifically at the impact of PELT enrollment on kindergarten-aged EFL learners' and their L1 literacy skill development.

3 For the sake of consistency, we use the term PELT throughout to refer to the context of this study: an early English foreign language program in public school, which we use synonymously with related terms English for young learners (EYL) and early English programs (EEP).

\section{Literature Review}

For five- and six-year-olds, one of the most important academic skills they begin to acquire in kindergarten is reading. A child's literacy skills are correlated to academic achievement across all subject areas (Wright, 2010). For bilingual children, there is robust evidence that children who first acquire strong literacy skills in their first language (L1) are able to transfer those skills to the second language (L2; August $\mathcal{E}$ Shanahan, 2006; Cárdenes-Hagan et al., 2007), a notion underpinned in theory by the linguistic interdependence hypothesis (Cummins, 1979). Often represented with the dual iceberg metaphor which illustrates how the development of common underlying proficiency (CUP) will be seen in any/all of a multilingual person's languages, the idea of linguistic interdependence is a crucial one for language learners in both foreign and second language learning contexts. Many educators in the United States promote approaches to bilingual education that foster biliteracy development (Escamilla et al., 2014) on the grounds that developing literacy in students' L1 will aid or even accelerate literacy development in English.

There are several recent studies that support this L1 $\rightarrow$ L2 connection. For example, in the U.S., Páez and Rinaldi (2006) found that for English-Spanish bilingual kindergarteners, their English phonological awareness (the ability to perceive sound-symbol correspondence for English phonemes and graphemes), English vocabulary (the number of high and low frequency words they know in English), and reading skills in Spanish (including decoding) were significant predictors of English word reading in first grade. However, the authors only identify students as low socioeconomic status, bilingual children (Páez E Rinaldi, 2006, p. 3), and do not discuss the types and quality of L1 and L2 literacy practices at home and school. While not surprising that emergent literacy skills in English in kindergarten predicted reading in English in grade 1, the correlation between early reading skills in Spanish and higher reading abilities in English reinforces the finding in other studies that there is strong positive transfer between L1 and L2 reading (Genesee, Geva, Dressler, \& Kamil, 2006), and that it can be long-term (Sparks, Patton, Ganschow, E Humbach, 2000). 
This finding also aligns with the study by CárdenesHagan, Carlson, and Pollard-Durodula (2007) of 1,016 kindergarten L1-Spanish English Language Learners (ELLs) in Texas, USA, which found that emergent bilingual readers with greater phonemic awareness in Spanish tended to be the ones with higher phonemic awareness in English. They found that the inverse was also true: students with lower letter name-to-sound recognition in the $\mathrm{L} 1$ were also lower in the $\mathrm{L} 2$. While this supports the argument for positive transfer of literacy skills (at least in the direction from L1 to L2), they interestingly found that $\mathrm{L} 2$ phonemic awareness was not correlated to general oral language proficiency. Proctor and colleagues (2011) have suggested that it is not just a question of positive transfer, but rather support for Cummins' (1979) linguistic interdependence hypothesis as mentioned above. Based on a study of 91 English-Spanish bilingual 4th graders in the U.S., Proctor et al. (2011) propose a model that posits that interdependence of literacy skills across both languages is strong for alphabetic knowledge, moderate for reading comprehension, and mild for Spanish oral language and English reading comprehension.

The consensus of the research is that L1 literacy skills can support development of the target language in English as a second language (ESL) contexts. What has not been examined is the case in EFL settings of the effects in the opposite direction; that is to say, to date few studies address the extent to which the linguistic interdependence theory is bi-directional. One exception is He's (2011) study of L1 Chinese learners of English in Hong Kong. She did not look at literacy skills per se, but found that other analytic skills done through literacy practices benefitted from crosslinguistic transfer. However, English has historically been used as a medium of instruction there, thus distinguishing Hong Kong from many other EFL contexts where exposure to English for most early learners consists of limited formal foreign language instruction in a classroom setting.

To explore whether the linguistic interdependence hypothesis with respect to the development of early literacy skills also has a significant effect in the $\mathrm{L} 2 \rightarrow \mathrm{L} 1$ direction, we posed the following research question:

Is there a difference in L1 literacy skills (in terms of letter/word identification, word/ sound association, dictation, narrative text comprehension, and informational text comprehension) between participants who were exposed to primary English language teaching (PELT) and those who were not?

\section{Methodology}

The following quantitative methodology was employed to compare the L1 literacy assessment performance of participants who hailed from four different schools in Mexico, two schools that implemented PELT instruction and two that did not.

\section{Context}

In 2009, Mexico launched one of the most ambitious English language programs in public schools in Latin America. Due to the country's geographic proximity and the close economic, social, and historical ties to the United States, the program aims to unify existing state and local initiatives and establish a common curriculum for teaching second language English as an academic subject across grades K-12. Starting in kindergarten, students receive 2.5 hours of instruction per week. By grade 9, the curriculum projects a total of 700 hours of instruction that will bring the student from an A0 to A2/B1- level on the Common European Framework of Reference scale (Council of Europe, 2001; Author, 2015b).

PELT instruction in Mexico includes various literacy elements, as Author (2015b) found in his qualitative analysis of the national EFL program. During the early English instructional time, for example, researchers documented a heavy emphasis on printed text in English textbooks for kindergarten, and many activities that included a literacy element, e.g., copying words, matching words to pictures, or tracing letters. Some teachers had been trained in the "Jolly Phonics Method," which emphasizes teaching the children the sounds of the letters, but not the name of the letter (i.e., " $\mathrm{B}$ " says / $\mathrm{b} /$ but without telling the children "this letter is called bee"). This approach to phonics contrasts with typical L1 Spanish literacy instruction, as phonemic awareness in L1 Spanish speaking contexts is often taught via syllabic approaches, rather than isolated phonemes (Goldenberg et al., 2014). 
However, other literacy elements supported by research on early English language teaching were less often observed in Author's (2015b) study. Less emphasis was placed on grapheme names, and common techniques for memorizing them, such as the ABC song, were not noted. Other research-supported techniques for interactive reading, such as story time or circle time, where the teacher reads to the group from a big book or authentic children's narrative text (Wasik \& Bond, 2001), were not observed. Finally, the EFL curriculum was not found to explicitly align with the L1 Spanish literacy curriculum, which, if aligned, could benefit both students and teachers in making cross-linguistic connections (Short, Cloud, Morris, \& Motta, 2012). Author 2's (2015b) study also noted that several stakeholder questions arose as to whether the PELT programs were impacting L1 literacy, and many of those interviewed, both educators and parents, wondered whether simultaneous or sequential approaches to literacy instruction were better for literacy skill development. For example, some parents, and even some general education teachers who did not teach English, had concerns that exposing children to literacy in English in the early grades (K-2) while they were still learning how to read in Spanish would create a kind of linguistic confusion that might delay their L1 literacy skills.

\section{Participants}

Participants included 61 first-grade children (aged 5-6 years) divided in two groups: an experimental group of those who had studied English in kindergarten and the first three bimesters (8 week periods) of primary school $(\mathrm{N}=31$ from schools 1 and 2; total of about 140 hours of L2 instruction), and a control group of those who had not ( $N=30$ from schools 3 and 4). Participants by school, program participation, and location can be seen in Table 1 . Children were randomly selected from all 1st graders in the school, and those who were identified by teachers as having some learning or reading delay (e.g., dyslexia) were not tested. The key differences in the teaching conditions among the suburban, urban, and rural schools were that the classrooms in the suburban and urban schools appeared to have more physical resources available, including newer desks and chalkboards, as well as additional facilities in the school such as conference rooms, etc. Teachers in the rural schools appeared to have fewer curriculum and instructional resources available. Instructional materials and curriculum resources tend to vary greatly from school to school, though, and as only four schools were included in the present study, we caution against making generalizations about teaching conditions and instructional materials to all public schools in this context.

Table 1: Participant Characteristics.

\begin{tabular}{cccc} 
School & $\begin{array}{c}\text { Number of } \\
\text { Participants }\end{array}$ & PELT Program & Location \\
\hline 1 & 14 & Yes & Suburban \\
2 & 17 & Yes & Urban \\
3 & 14 & No & Suburban \\
4 & 16 & No & Rural \\
\hline
\end{tabular}

\section{Instrumentation}

To operationalize literacy skill development for the EFL context in Mexico, the authors adapted a quantitative measure of early literacy and entitled it the Early Spanish Literacy Assessment (ESLA). The instrument includes five sub-tests, two of which (1 and 3) are based on an existing instrument, the Woodcock Language Proficiency Battery-Revised: Spanish Form (Woodcock \& Muñoz-Sandoval, 1995) which has been extensively validated across a range of populations (see Páez \& Rinaldi, 2006). The authors designed the remaining sub-sections (2, 4, and 5) to align with the Mexican curriculum and approach to literacy acquisition. Consistent with the curriculum at ages 6-7, the authors included four sub-tests to evaluate various aspects of reading, and one (Section 3) to evaluate writing (see Table 2). The instrument was piloted and revised several times to remove ambiguities (e.g., cultural relevance of pictures used) and to promote consistency of test administration and scoring among raters.

\section{Procedures}

The test was administered individually to students in the four schools during the month of 
Table 2: Early Spanish Literacy Assessment Constructs and Sub-Tests.

\begin{tabular}{|c|c|}
\hline Construct & Sub-Tests \\
\hline \multirow{5}{*}{$\begin{array}{l}\text { Identification of letters and words } \\
\text { (38 items worth } 1 \text { point each) }\end{array}$} & Recognition of letters \\
\hline & Recognition of upper and lower case letters \\
\hline & Reading sight words \\
\hline & Reading high frequency two-syllable words \\
\hline & Reading multiple syllable and lower frequency words \\
\hline \multirow{4}{*}{$\begin{array}{l}\text { Association of words and sounds } \\
\text { (28 items worth } 1 \text { point each) }\end{array}$} & Recognition of rhymes \\
\hline & Production of rhymes \\
\hline & Recognition of initial phonemes \\
\hline & Division of syllables \\
\hline \multirow{5}{*}{$\begin{array}{l}\text { Dictation } \\
\text { (20 items worth } 1 \text { point each) }\end{array}$} & Written production of consonants and vowels \\
\hline & Written production of upper case letters for proper nouns \\
\hline & Written production of common punctuation \\
\hline & Written production of simple words \\
\hline & Written production of plural forms \\
\hline Reading narrative text & Reading speed (measured in words per minute) \\
\hline (two texts with 83 and 92 words, respectively; 4 fluency & Reading fluency (measured by number of miscues) \\
\hline constructs worth 25 points total; 4 comprehension questions & Reading comprehension (measured by answers to 4 \\
\hline worth 8 points total) & comprehension questions covering narrative elements) \\
\hline \multirow{4}{*}{$\begin{array}{l}\text { Reading informational texts } \\
\text { (one text with } 79 \text { words; } 4 \text { fluency constructs worth } 25 \text { points } \\
\text { total; } 4 \text { comprehension questions worth } 8 \text { points total) }\end{array}$} & Reading speed (measured in words per minute) \\
\hline & Reading fluency (measured by number of miscues) \\
\hline & Reading comprehension (measured by answers to 4 \\
\hline & comprehension questions covering informational text elements) \\
\hline
\end{tabular}

January 2015. For each school, students were chosen randomly from first graders who did not present any reading disabilities (e.g., dyslexia) and whose parents had given consent to participate. The test took from 25-30 minutes per student, and was administered by L1 Spanish-speaking members of the research team. Raw scores were recorded and stored for analysis. Then, a one-way independent samples comparison of means was conducted on the participants' total composite scores, as well as on each sub-test of the ESLA: letter/word identification, word/sound association, dictation, narrative text reading, and informational text reading.

\section{Results}

Overall, the one-way independent samples comparison of means revealed significant differences between the two groups. Descriptive statistics are presented in Table 3; results from one-way independent samples t-test on sub-tests and total scores can be seen in Table 4 .

Due to the importance of reading narrative and informational text as academic skills, we also analyzed each of those constructs by sub-test, as seen in Tables 5 and 6 below. 
Table 3: Mean, Standard Deviation, and range on ESLA Composite and Sub-tests by Group.

\begin{tabular}{|c|c|c|c|c|c|c|c|}
\hline Group & & Composite & $\underline{\text { Word ID }}$ & $\begin{array}{c}\text { Word } \\
\text { Association }\end{array}$ & Dictation & $\underline{\text { Narrative Text }}$ & Informational Text \\
\hline & Mean & 375.96 & 31.45 & 18.48 & \multirow[b]{2}{*}{$15.83(2.94)$} & \multirow[b]{2}{*}{$99.93(62.86)$} & 45.79 \\
\hline PELT & SD & (205.60) & (7.05) & (5.4) & & & (34.42) \\
\hline Exposure & & & & & \multirow[t]{2}{*}{16} & \multirow[t]{2}{*}{234.2} & \\
\hline & Range & 749.8 & 29 & 18 & & & 102.8 \\
\hline No PELT & Mean & 191.25 & 24.87 & 10.56 & \multirow{2}{*}{$13.06(4.81)$} & \multirow{2}{*}{$\begin{array}{l}47.75 \\
(51.58)\end{array}$} & 17.96 \\
\hline Exposure & SD & $(174.71)$ & $(10.5)$ & $(6.92)$ & & & (27.97) \\
\hline & Range & 643 & 30 & 24 & 19 & 190.7 & 91.8 \\
\hline
\end{tabular}

Table 4: Independent Samples t-test Results on ESLA Composite and Sub-Tests.

\begin{tabular}{|c|c|c|c|c|c|c|}
\hline & Composite & Word ID & Word Association & Dictation & Narrative Text & Informational Text \\
\hline$t_{(59)}$ & 3.775 & 2.882 & 4.974 & 2.726 & 3.539 & 3.458 \\
\hline$\stackrel{(59)}{p}$ & .000 & .006 & .000 & .008 & .001 & .001 \\
\hline
\end{tabular}

Table 5: Narrative Text Reading Sub-Test Results by Group.

\begin{tabular}{ccccc}
\hline Group & & $\underline{\text { Rate }}$ & Fluency & Comprehension \\
& Mean & 13.24 & 31.65 & 5.2 \\
PELT Exposure & SD & $(7.83)$ & $(22.48)$ & $(6.03)$ \\
& Range & 90.6 & 23 & 8 \\
No PELT Exposure & Mean & $13.54(16.01)$ & 7.82 & 2.65 \\
& SD & 65.35 & $(7.97)$ & $(3.02)$ \\
\hline
\end{tabular}

Table 6: Informational Text Reading Sub-Test Results by Group.

\begin{tabular}{ccccc}
\hline Group & Mean & Rate & Fluency & Comprehension \\
PELT Exposure & SD & $28.72(23.47)$ & $12.4(8.99)$ & $(3.17)$ \\
& Range & 75.2 & 24 & 8 \\
No PELT Exposure & Mean & & & 1.47 \\
& SD & $10.3(16.8)$ & $6.17(9.05)$ & $(2.43)$ \\
& Range & 60.8 & 23 & 8 \\
\hline
\end{tabular}




\section{Discussion of Results}

When the mean scores of the PELT exposure and No PELT exposure groups were compared, the participants exposed to PELT scored significantly higher on all sub-tests of the ESLA, as well as had significantly higher total composite scores on the ESLA. Still, a wide range of scores existed both among and between participant groups on each of those sub-tests and the composite. The discussion that follows is framed according to each sub-test, and then the composite scores of the ESLA.

\section{Word Identification}

In terms of word identification, a significant difference in mean scores was found between the experimental and control groups. Children in the group who had been studying English were better able to identify words in Spanish. The experimental group (PELT) scored an average of 31 out of 38 points (one point per item), which means they were able to identify about $82 \%$ of the letters and words on this section. The control group correctly identified an average of 25 out of 38 , or $66 \%$ of the items. As the word identification tasks were either correctly indicating a letter or word when told to do so orally by the test administrator, or correctly reading a letter or word indicated by the test administrator, these results may indicate that the PELT participants overall had a larger Spanish sight word vocabulary than the non-PELT participants. As Peregoy and Boyle (2016) assert, much of students' sight word vocabulary is developed "as a result of immersion in meaningful, functional encounters with print [as well as] explicit instruction on strategies they can use to recognize words they have not encountered before" (p. 184). The increased time spent studying English may have afforded PELT participants more encounters with print in general, as well as with the more explicit language teaching strategies that tend to be present in second or foreign language classroom settings (Ellis, 2008).

\section{Word Association}

PELT participants also scored significantly higher on word association items, averaging 18 out of 28 possible points, or $64 \%$ correct. Students who were not exposed to English fared much lower, averaging only 10 out of 28 , or $36 \%$ correct. The higher score of the PELT students might be attributed to the presence of English-based phonics instruction that asked them to recognize rhymes, produce rhymes, recognize initial phonemes, and divide syllables. It is possible that, during the English-based phonics instruction, explicit links between the phonemic inventories of Spanish and English were made, a practice demonstrated to promote levels of phonemic awareness in young readers and help them more readily transfer understanding about similarities of letter sounds in both languages (Herrera, Perez, \& Escamilla, 2010).

\section{Dictation}

Participants in the PELT group performed significantly higher on the dictation tasks than the non-PELT group, as well ( 16 out of 20 , or $80 \%$ correct, and 13 out of 20 , or $65 \%$ correct, respectively). Studying English over time may afford learners a better understanding of orthographic systems and phoneme-grapheme correspondence (Bialystok E Barac, 2012), especially given the shallow orthography of Spanish and the deep orthography of English (Geva \& Wang, 2001). Even though the PELT learners had studied English for a relatively short amount of time ( 2.5 hours a week for about 1.5 years at the time of testing), they performed better than their counterparts. The difference in performance may be related to the highly and positively correlated writing systems of Spanish and English in terms of content, punctuation, and conventions, which Geisler, Escamilla, Hopewell and Ruiz (2007) found in their longitudinal study of Spanish/English bilinguals in grades 1-4. Thus, the extra time spent learning to write in English may have helped PELT participants write dictated letters and words in Spanish.

\section{Narrative Text}

Given their scores on the discrete skills discussed above, it is unsurprising that, via the differences that emerged in the results on participants' ability to read narrative text, PELT participants fared significantly better on this sub-test, as seen in Table 5 . While both groups read at a similar rate, on average, the PELT group read more accurately (31.65 words vs. 7.82 in the non-PELT group) and answered an average of 5 of the 8 comprehension questions accurately, while 
non-PELT participants averaged only 3 out of 8 correct comprehension questions. These comprehension scores are important, as comprehension is, in fact, the sense-making part of reading print (Vaughn $\varepsilon$ Linan-Thompson, 2004). Because comprehending narrative text requires readers to "summon up frameworks of stored knowledge from their memories," as Temple et al. (2008, p. 193) describe schema theory, one possible explanation for the PELT group's performance is that participation in an L2 learning experience increased their schematic framework about certain concepts or word learning. Another way in which PELT exposure may influence narrative text fluency and comprehension lies in the relationship between oral language development and literacy development (August, Shanahan, $\mathcal{E}$ Escamilla, 2009; Temple et al. 2008). Even though oral language activities might have occurred in the PELT class in English, the additional exposure to reading aloud, social interaction, and classroom dialogues-tenets of L2 instruction-may have assisted the PELT participants as they developed literacy skills surrounding narrative text.

\section{Informational Text}

As a whole group, participants scored lower on the informational text sub-test than the narrative text sub-test and had fewer participants who were able to complete the tasks at all. Performance on informational text tasks was also another point of division for PELT participants, as those who had exposure to English performed better on the task with a mean score of $45.79(\mathrm{SD}=34.42)$ over the nonPELT group, whose mean score was 17.96 (SD = 27.97). In examining the Informational Text sub-test by section, both groups had participants who were unable to complete the reading task, which is not uncommon for children in early grades of elementary school; this resulted in a wide range of scores in both groups. Still, the PELT group performed higher in fluency, rate, and text comprehension than the non-PELT students, who struggled most with comprehending the informational text passage. Their mean comprehension score was a 1.47 (SD $=2.43$ ) out of 8 possible points, while the PELT group averaged a score of $4.65(\mathrm{SD}=3.17)$. Out of the 14 students who scored a 7 or an 8 on the comprehension section, only one was from the non-
PELT group, while out of the 28 students who did not answer any of the comprehension questions correctly, 20 of them were from the non-PELT group.

This division is congruent with previous findings supporting the key role of vocabulary (perhaps PELT participants had more access to vocabulary development in their English classes) in reading comprehension (Proctor, August, Carlo, E Snow, 2006), as well as the cognate recognition skills that word identification (operationalized in the first sub-test) could afford students if or when they develop reading abilities in two languages (August, Carlo, Dressler, \& Snow, 2008). While the PELT group did post higher scores than their counterparts, overall neither group scored highly on the comprehension section, which might be attributed to age and informational text structure. Younger students may be more familiar with the narrative text structure common in stories, fairy tales, and other narrative genres, and less familiar with the attributive, compare/contrast, problem/ solution, or cause/effect expository text structures prominent in informational text (Peregoy $\mathcal{E}$ Boyle, 2016). In addition, informational text, which tends to be more academic in nature, may include academic language that contains more technical vocabulary, multi-syllabic words, more complex grammatical structures, discipline-specific conventions of use, and higher cultural and experiential demands placed on students (Schleppegrel, 2007). Society itself is trending more toward informational text reading, especially due to our saturation of information via technology use (Hull \& Moje, 2012; Temple et al., 2008); as such, school systems are shifting to promote more informational text instruction, as seen in the United States' Common Core State Standards (Van Lier $\mathcal{E}$ Walqui, 2012). Thus, it is worth attending to the role that PELT instruction may play in informational text learning in EFL contexts.

\section{Composite Scores}

With regard to the composite scores, the PELT group performed significantly better overall than the non-PELT group. While this finding is noteworthy, the descriptive statistics indicate great variation in the scores both between and among participants in the two groups. Even by the second term of first 
grade, there were vast differences in the $\mathrm{L} 1$ reading abilities of students: in every school there was at least a 500-point difference between the top readers and those with the lowest scores (total scores ranged from 7.0 to 776.8 ). This is also supported by the high standard deviations reported by the comparison of means on both composite scores and sub-test of the ESLA (see Table 3). Also, the samples included only the students reading on their expected grade level in each school, since children identified by the teacher as having learning issues (including dyslexia and other reading problems) were excluded. For example, according to the teacher in School 4, the 14 children tested constituted all the normal readers in that school, since the rest (almost half the group of 1st graders) could not yet read at all due to what the school called learning disabilities. This variation should be of interest to program administrators or government programs who seek to improve both the English language proficiency and the L1 literacy of the students in their school systems, as a one size fits all approach to EFL instruction may be less effective due to the great variation in participants' L1 literacy trajectories, as demonstrated in the current study.

\section{Conclusions}

Ultimately, it appears that studying PELT did not hinder L1 literacy development, and may in fact provide a slight boost for children in L1 literacy development. These findings suggest that the linguistic interdependence hypothesis, which research has shown holds from L1 $\rightarrow$ L2, likely also has positive effects related to literacy development in the other direction, from L2 $\rightarrow$ L1 (at least for alphabetic languages sharing a similar orthography like English and Spanish). For early L2 curriculum development, these findings support a program designed to give simultaneous exposure to English and Spanish literacy from kindergarten, rather than a sequential approach (i.e., only introducing oral skills in L2 until about $3^{\text {rd }}$ grade, until after a strong basis of L1 literacy has been developed). However, we would also caution that it may not be just any exposure to L2 that aids L1 literacy development, and that further research could shed light on what pedagogical approaches could best support linguistic interdependence. Likewise, in Mexico we can anticipate that better alignment and coordination between the English teacher and the general education teacher working with L1 Spanish literacy (for example, explicit attention to differences between the languages to help cross-linguistic phonemic awareness) could also foster greater gains.

Given the degree to which the results are statistically significant, it is unlikely that PELT exposure is the only variable contributing to the explanation of variance between the two groups in the present study. First, our study did not account for the role of home literacy practices among the participants, such as time spent reading daily, or the inclusion of students' funds of knowledge (González, Moll, \& Amanti, 2006). Home literacy practices and funds of knowledge incorporation have been found to positively impact students' literacy development, and future research could seek to account for those factors as they fell outside the scope of the present study. Another potential limitation of the study was that the participants did not all come from schools of equal socioeconomic status, which is supported in the literature as a variable impacting reading performance and literacy skill development in general (Aikens \& Barbarin, 2008).

In addressing literacy development and SES, Chiu and Chow (2014) describe a complex, ecological system theory model that accounts for the mechanisms that produce observable differences in reading achievement amongst students according to their SES, which would be an additional way to investigate this topic moving forward. While we can initially conclude that introducing one kind of pedagogical enrichment-foreign language instruction, even starting in kindergarten and with attention to literacy skills - may help L1 literacy, there is no guarantee that PELT exposure would provide enough of a support within the broader social ecology of the child to produce much measurable positive effect on L1 literacy development, as is often claimed.

The study was motivated by our hope that starting English exposure early and including literacy elements into a PELT program, might encourage biliteracy development and motivate children to become more engaged with literacy across languages. Our findings in comparing the mean scores on the literacy assessment sub-tests 
and composite scores support a positive influence of PELT programs on L1 literacy development. Still, in conducting our study, we found that wider issues of tension and unequal access to PELT programs exist. The expansion of early English programs in public schools in Mexico, Latin America, and around the world is strongly motivated by the notion that introducing English in public primary schools will lead to greater opportunities and mobility for poor and working class students (Author, 2015a).

While thecurrentstudysupports apotential positive impact of PELT programs on L1 literacy development, scholars and program administrators should still call into question the assumption that PELT programs will automatically lead to socioeconomic mobility for lower SES students. They may, in fact, reinforce existing social class advantages, as wealthier children have more access to English, and therefore the social opportunities that bilingualism affords, while children from poor areas do not. PELT programs in countries like Mexico are not, in and of themselves, a panacea that fixes social, educational, and economic inequities for lower SES children. Rather, PELT programs in public schools should be carefully implemented in a way that takes into account schools' socioeconomic context and is integrated to support students' learning across the curriculum.

A further consideration is that, in the Latin American context, English language policies are not always implemented without critique from local stakeholders (as seen in Author, 2015b) on behalf of the parents whose children were enrolled in PELT programs), and much of English language education policy interpretation is often highly specific to both context and personnel (Hornberger $\mathcal{E}$ Cassels Johnson, 2007). In addition, the presence of English in many Latin American communities represents a third language for students who are L1 speakers of indigenous languages (López, 2009), which may further compound the relevance of and interest in English learning. Despite the discourse of the promises connecting the English language to modernization of education systems, greater competitiveness in global markets, and increased socioeconomic opportunities for individuals, the importance of understanding how global and local ("glocal") forces impact both policy implementation and resistance regarding PELT programs remains.

\section{References}

Aikens, N. L., \& Barbarin, O. (2008). Socioeconomic differences in reading trajectories: The contribution of family, neighborhood, and school contexts. Journal of Educational Psychology 100(2), 235-251.

August, D., Carlo, M., Dressler, C., E Snow, C. (2005). The critical role of vocabulary development for English language learners. Learning Disabilities Research $\mathcal{E}$ Practice, 20(1), 50-57.

August, D., Shanahan, T., E Escamilla, K. (2009). English language learners: Developing literacy in secondlanguage learners-Report of the National Literacy Panel on Language-Minority Children and Youth. Journal of Literacy Research, 41(4), 432-452.

Sayer, P. (2015a). Expanding global language education in public primary schools: The national English program in Mexico. Language, Culture \& Curriculum, 28(3), 257-275.

Sayer, P. (2015b). 'More $\varepsilon$ earlier': Neoliberalism and primary English education in Mexican public schools. L2 Journal, 7(3), 40-56.

Bialystok, E., \& Barac, R. (2012). Emerging bilingualism: Dissociating advantages for metalinguistic awareness and executive control. Cognition, 122(1), 67-73.

Cárdenes-Hagan, E., Carlson, C. D., \& Pollard-Durodola, S. D. (2007). The cross-linguistic transfer of early literacy skills: The role of initial L1 and L2 skills and language of instruction. Language, Speech, and Hearing Services in Schools, 12(3), 249-259.

Chiu, M. M., \& Chow, B. (2014). Classmate characteristics and student achievement in 33 countries: Classmates' past achievement, family socioeconomic status, educational resources, and attitudes towards reading. Journal of Educational Psychology, 107(1), 152-169.

Council of Europe. (2001). Common European framework of reference for languages. Cambridge, UK: Cambridge University Press.

Cummins, J. (1979). Linguistic interdependence and the educational development of bilingual children. Review of Educational Research, 49(2), 222-251.

Ellis, R. (2008). Understanding second language acquisition. Oxford, UK: Oxford Press.

Enever, J. (2012). Current policy issues in early foreign language learning. CEPS Journal, 2(3), 9-26.

Escamilla, K., Hopewell, S., Butvilofsky, S., Sparrow, W., Soltero-González, L., Ruiz-Figueroa, O., \& Escamilla, M. (2014). Biliteracy from the start: Literacy squared in action. Philadelphia, PA: Caslon. 
Escamilla, K., Hopewell, S., Geisler, D., \& Ruiz, O. (2007). Transitions to biliteracy: Beyond Spanish and English. American Educational Research Association Conference Proceedings.

Genesee, F., Geva, E., Dressler, C., \& Kamil, M. (2006). Synthesis: Cross-linguistic relationships. In D. August $\varepsilon$ D. Shanahan (Eds.), Developing literacy in second-language learners (pp. 153-174). Mahwah, NJ: Lawrence Erlbaum.

Geva, E., \& Wang, M. (2001). The development of basic reading skills in children: A cross-linguistic perspective. Annual Review of Applied Linguistics, 21, 182-204.

Goldenberg, C., Tolar, T. D., Reese, L., Francis, D. J., Bazán, A. R., E Mejía-Arauz, R. (2014). How important is teaching phonemic awareness to children learning to read in Spanish? American Educational Research Journal, 51(3), 604-633.

González, N., Moll, L. C., \& Amanti, C. (Eds.). (2006). Funds of knowledge: Theorizing practices in households, communities, and classrooms. New York, NY: Routledge.

Hamid, M. O. (2010). Globalisation, English for everyone and English teacher capacity: Language policy discourses and realities in Bangladesh. Current Issues in Language Planning, 11(4), 289-310.

He, A. E. (2011). Educational decentralisation: A review of popular discourse on Chinese-English bilingual education. Asia Pacific Journal of Education, 31: 91-105.

Herrera, S. G., Perez, D. R., E Escamilla, K. (2011). Teaching reading to English language learners: Differentiating literacies. Boston, MA: Pearson Higher Ed.

Hornberger, N. H. \& Johnson, D. C. (2007). Slicing the onion ethnographically: Layers and spaces in multilingual language education policy and practice. TESOL Quarterly, 41(3), 509-532.

Hull, G. A., \& Moje, E. B. (2012). What is the development of literacy the development of? In

K. Hakuta, \& M. Santos (Eds.). Understanding language: Language, literacy, and learning in the content areas (pp. 52-63). Palo Alto, CA: Stanford University.

Knell, E., Qiang, H., Pei, M., Chi, Y., Siegel, L. S., Zhao, L., \& Zhao, W. (2007). Early English immersion and literacy in Xi'an, China. The Modern Language Journal, 91(3), 395-417.

López, L. E. (2014). Indigenous intercultural bilingual education in Latin America: Widening gaps between policy and practice. In R. Cortina (Ed.), The education of indigenous citizens in Latin America (pp. 19-49). Bristol, UK: Multilingual Matters.
Nikolov, M., \& Djigunovic, J. M. (2006). Recent research on age, second language acquisition, and early foreign language learning. Annual Review of Applied Linguistics, 26, 234-260.

Páez, M., \& Rinaldi, C. (2006). Predicting English word reading skills for Spanish-speaking students in first grade. Topics in Language Disorders, 26(4), 338350.

Peregoy, S., E Boyle, O. (2016). Reading, writing and learning in ESL. Boston, MA: Pearson.

Proctor, C. P., August, D., Carlo, M. S., \& Snow, C. (2006). The intriguing role of Spanish language vocabulary knowledge in predicting English reading comprehension. Journal of Educational Psychology, 98(1), 159-169.

Proctor, C. P., August, D., Snow, C., \& Barr, C. D. (2011). The interdependence continuum: A perspective on the nature of Spanish-English bilingual reading comprehension. Bilingual Research Journal, 33(1), 5-20.

Schleppegrell, M. J. (2007). The linguistic challenges of mathematics teaching and learning: A research review. Reading \& Writing Quarterly, 23(2), 139-159.

Short, D. J., Cloud, N., Morris, P., \& Motta, J. (2012). Crossdistrict collaboration: Curriculum and professional development. TESOL Journal, 3(3), 402-424.

Sparks, R., Patton, J., Ganschow, L., \& Humbach, N. (2009). Long-term crosslinguistic transfer from L1 to L2. Language Learning, 59(1), 203-243.

Temple, C., Ogle, D. Crawford, A., \& Freppon, P. (2008). All children read: Teaching for literacy in today's diverse classrooms. Boston, MA: Pearson.

Van Lier, L., \& Walqui, A. (2012). Language and the common core state standards. Understanding Language: Commissioned Papers on Language and Literacy Issues in the Common Core State Standards and Next Generation Science Standards, 94, 44-51.

Wasik, B. A., E Bond, M. A. (2001). Beyond the pages of a book: Interactive book reading and

language development in preschool classrooms. Journal of Educational Psychology, 93(2), 243-250.

Woodcock, R. W., \& Muñoz-Sandoval, A. F. (1995). Woodcock language proficiency battery-revised: Spanish form. Itasca, IL: Riverside Publishing.

Wright, W. (2010). Foundations for teaching English language learners: Research, theory, policy, and practice. Philadelphia, PA: Caslon. 